\title{
Tropical Orb Weaver Spider, Eriophora ravilla (C. L. Koch) (Arachnida: Araneae: Araneidae) ${ }^{1}$
}

G. B. Edwards ${ }^{2}$

\section{Introduction}

Among the several large orb weavers occurring in Florida is Eriophora ravilla (C.L. Koch). Unlike similar large spiders of the genus Neoscona (Edwards 1984), E. ravilla is not a conspicuous member of the diurnal fauna during its adult stage. Nevertheless, nursery inspectors regularly encounter specimens of this species and submit them to the Division of Plant Industry for identification. Bites of this species are not known to cause serious effects to humans.

\section{Distribution}

Eriophora ravilla belongs to a genus of primarily tropical species. Its range is largely circum-Caribbean, occurring in Florida, Louisiana, and Texas along the Gulf Coast of the United States; Mexico; throughout Central America; throughout the Greater and Lesser Antilles; the Bahamas; and in Colombia and Venezuela in northern South America. The extremes of its range are two disjunct records, one from Maryland in the U.S.A. and one from southeastern Brazil (Levi 1970).

\section{Description}

Females vary from 12-24 mm in length and from nearly white to nearly black in color. Typically in Florida, females have a mostly reddish-brown cephalothorax and legs, with darker femora. The dorsum of the abdomen is gray to brown. The venter of the abdomen has a black triangular mark pointing posteriorly; this mark is surrounded by gray laterally and by white anteriorly and posteriorly (Levi 1970). In life, the anterior lateral corners of the abdomen are frequently bright yellow; unfortunately, this color fades to gray after lengthy preservation in alcohol. The integument is covered with white setae, especially on the carapace and legs.

Males vary from $9-13 \mathrm{~mm}$ in length. They are similar to females in color. The abdomen is much smaller than that of the female and is usually dark gray. The legs are usually banded. The carapace has a deep longitudinal thoracic groove (Levi 1970). When the male is actively moving about, its palpi can be seen as large anterior structures which appear to flare out to the sides.

1. This document is EENY-291 (originally published as DPI Entomology Circular 286), one of a series of Featured Creatures from the Entomology and Nematology Department, Florida Cooperative Extension Service, Institute of Food and Agricultural Sciences, University of Florida. Published: June 2003. This document is also available on Featured Creatures Website at http://creatures.ifas.ufl.edu. Please visit the EDIS Website at http://edis.ifas.ufl.edu. Additional information on these organisms, including many color photographs, is available at the Entomology and Nematology Department website at http://entnemdept.ifas.ufl.edu/.

2. G. B. Edwards, Florida Department of Agriculture and Consumer Services, Division of Plant Industry, Gainesville, FL.

The Institute of Food and Agricultural Sciences (IFAS) is an Equal Employment Opportunity - Affirmative Action Employer authorized to provide research, educational information and other services only to individuals and institutions that function without regard to race, creed, color, religion, age, disability, sex, sexual orientation, marital status, national origin, political opinions or affiliations. For information on obtaining other extension publications, contact your county Cooperative Extension Service office. Florida Cooperative Extension Service / Institute of Food and Agricultural Sciences / University of Florida / Larry R. Arrington, Interim Dean 


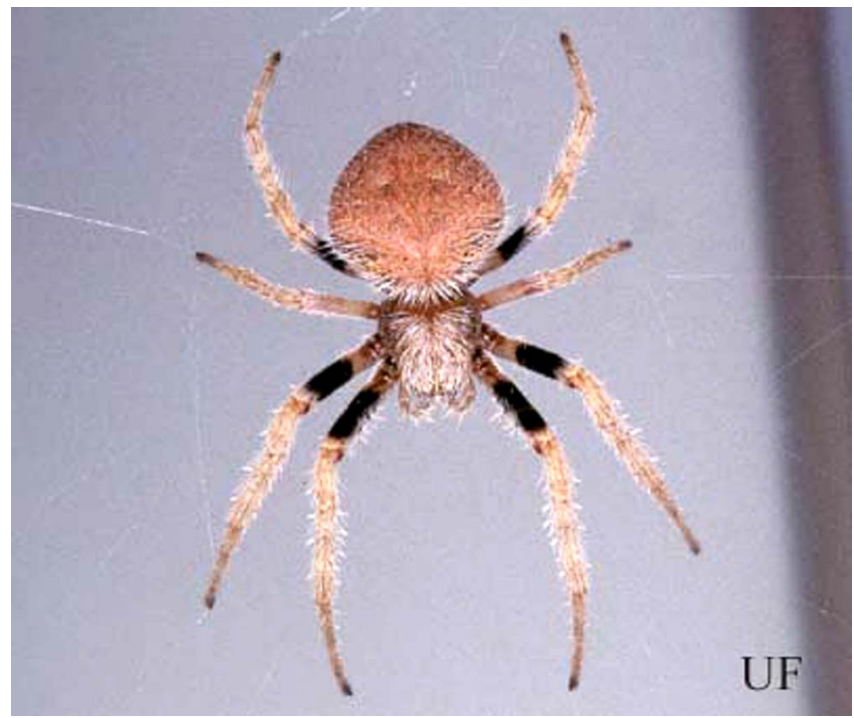

Figure 1. Female sub-adult or adult tropical orb weaver, Eriophora ravilla (C.L. Koch). Credits: Lyle J. Buss, University of Florida

Color and pattern variation is extensive in Florida juvenile specimens and in adults in more tropical areas. The abdominal dorsum may have a pattern of white spots, may have a narrow central white stripe, the entire dorsum may be brilliant green in life, and two humps may be present posteriorly. The latter character, when present, further enhances the resemblance of juveniles to the genus Eustala, with which they are frequently confused (Levi 1970).

\section{Habits and Habitat}

E. ravilla inhabits open woodland, ranging from live oak in scrub areas to "hammock" (Levi 1970). I have found it most frequently in mesophytic situations. Where the understory is fairly dense, $E$. ravilla will make webs in the tree canopy. I have taken a female from the top of a television antenna, about $16 \mathrm{~m}$ above ground.

Orb webs of adult female $E$. ravilla have a widely spaced spiral and may be over $1 \mathrm{~m}$ across (see photograph in Levi 1977). The bridge thread supporting the web may be $6 \mathrm{~m}$ long (M. Stowe in Levi 1977). The web is constructed after dark and the orb is taken down before dawn. The bridge and frame threads are probably left in place (Levi 1977). The web probably catches many moths and other night flying insects; these spiders may be particularly beneficial along woodland borders of field agroecosystems and within orchards. It is known to

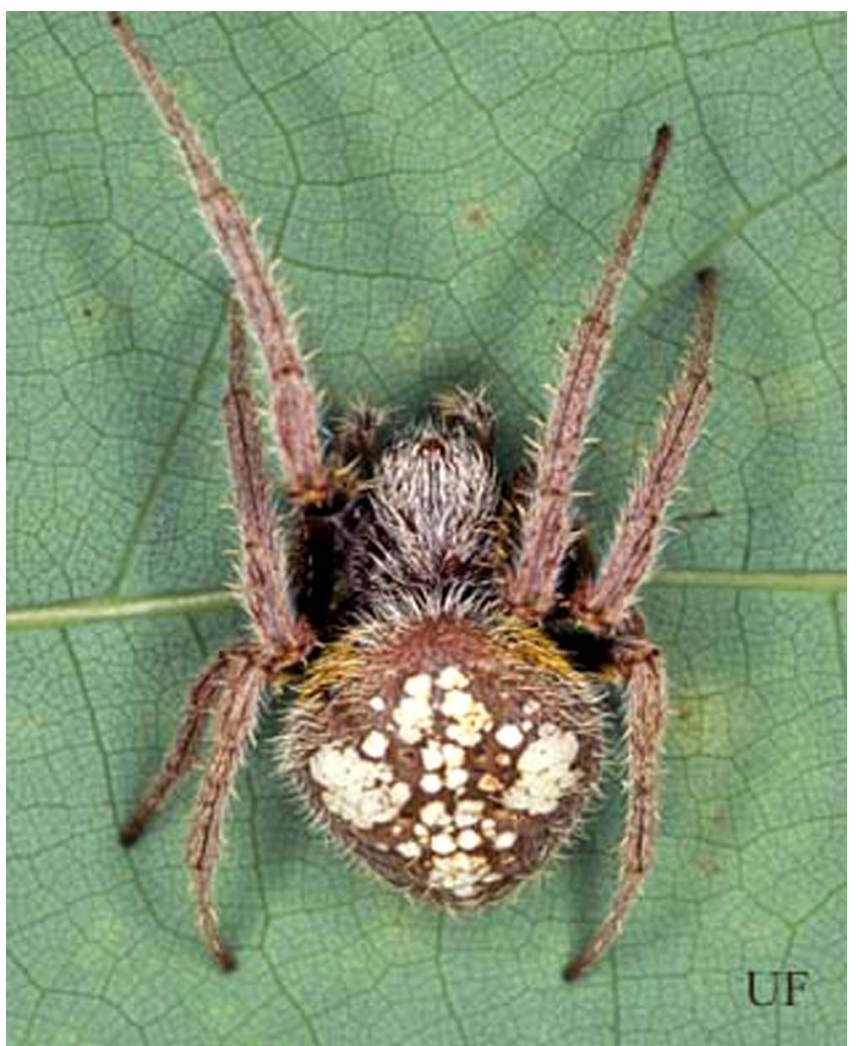

Figure 2. Sub-adult tropical orb weaver, Eriophora ravilla (C.L. Koch). Credits: James L. Castner, University of Florida

occur in citrus groves in Florida (Mansour et al. 1982). All stages apparently occur throughout the year, but little else is known of its life cycle.

\section{Survey and Detection}

During the day, E. ravilla may be found on the underside of leaves which are partially rolled and tied with silk, or occasionally in sparse silken retreats in sheltered corners of man-made structures. At night, the spiders may be seen hanging head down at the center of their webs. They may be captured in large vials and preserved in 70-80\% alcohol (ethanol or isopropanol). An easy way to capture one alive is to put a plastic bag around the leaf containing the spider in its diurnal retreat, and then cut the leaf from the branch.

\section{Selected References}

Edwards GB. 1984. Large Florida orb weavers of the genus Neoscona (Araneae: Araneidae). Florida Department of Agriculture and Consumer Services, Entomology Circular 266: 1-2. 
Levi HW. 1970. The Ravilla group of the orb weaver genus Eriophora in North America (Araneae: Araneidae). Psyche 77: 280-302.

Levi HW. 1977. Caught in the intrigue of spider orb-webs. The Science Teacher 44: 16-19.

Mansour F, Ross JW, Edwards GB, Whitcomb WH, Richman DB. 1982. Spiders of Florida citrus groves. Florida Entomologist 65: 514-522. 